\title{
How effective have measures by Central Banks been in mitigating the
} impact of financial crisis?

\author{
Ibrahim S. Rimintsiwa \\ Nile University of Nigeria, Abuja. \\ tsiwa001@yahoo.com
}

\begin{abstract}
During the global financial crisis, central banks around the globe implemented a series of unconventional monetary policy measures such as quantitative easing among others to avert the impact of financial crisis on financial system. There exist numerous studies on this area of interest, with each guided by a specific view of the problem and selectively chosen empirical observations with regard to the different developments. This paper reviewed literature to ascertain the effectiveness of conventional monetary policy measures and unconventional monetary measures used in mitigating the impact of the 2007/2008 global financial crisis, specifically by the major central banks including the Federal Reserve, European Central Bank and Bank of England. The study used systematic quantitative assessment technique (SQAT) to determine a high quality of papers that have been reviewed in the study. The result proved that conventional monetary policy measures are still potent to deliver their desired objectives but inadequate in times of acute crisis. Empirical evidences proved that central banks have not practically abandoned the core elements of their pre-crisis monetary policy. Through a complex form of strengthening and reassessment, they have instead complimented, extended and somewhat improved their measures to mitigate the impact of the financial crisis. An important lesson of the crisis is that there is opportunity to reinforce central banks with macro prudential supervision and regulation. This should be seen as complementary to the existing monetary policy measure in order to deliver the twin objectives of price and financial stability.
\end{abstract}

Keyword: Financial Crisis, Central Banks, Monetary Policy, Conventional Measures and Unconventional Measures

\section{INTRODUCTION}

"The financial crisis of 2007-2009 has been called the worst financial crisis since the one related to the Great Depression by leading economists, and it contributed to the failure of key businesses, declines in consumer wealth estimated in the trillions of U.S. dollars, substantial financial commitments incurred by governments, and a significant decline in economic activity" (Nastase et al., 2010, p. 691). Since the occurrence of this global crisis, there has been growing concern among central bankers, government, scholars and other stakeholders on the measures and role of central banks in mitigating future financial crisis (Da Silva \& Viera 2017; Khan, 2017; Oritani, 2019). Financial crisis can be described as any unusual economic situation where by the financial value of many assets drop significantly in a short amount of time (Gertler \& Gilchrist, 2018). These are periods associated with significant decline in spending, leading to a substantial disruption of credit flows and slow economic growth (Mamun, 2017). The ultimate indicators of financial crises include bank failures, stock market crashes, and currency crises, which may lead to deep recession (Aliber \& Zoega, 2019). 
The 2007/2008 Global Financial Crisis has sparked a growing body of conceptual and empirical studies analyzing what went wrong, lessons learnt and how to prevent future financial crisis (Bakir, 2017; Mishkin, 2017; Aliber \& Zoega, 2019). Even though much has already been written and widely discussed in many ways on this area of interest, each treatment is largely guided by a specific view of the problem and selectively chosen empirical observations with regard to the different developments (Bakir, 2017; Mishkin, 2017; Cukierman, 2019). Indeed, the crisis that emerged worldwide in 2008 required a systemic intervention by the central banks, particularly of advanced countries, thereby compelling them to review their monetary policy approaches (Rajan, 2017; Oritani, 2019; Cukierman, 2019). Existing literatures revealed that most central banks deployed unconventional measures in mitigating the tremendously negative impact of the global financial crisis on the global economy (Rajan, 2017; Gertler \& Gilchrist, 2018; Cukierman, 2019). Most studies focused and emphasized how the crisis were mitigated using unconventional measures without focusing on the effectiveness of the conventional measures in achieving their desired objectives.

The Global Financial Crisis of 2007/2008 was more rapid and decisive compared to the Great Depression due to the fact that we learned from the past (Correia \& Martins, 2017, Cukierman, 2019; Aliber \& Zoega, 2019). It is therefore imperative to study economic crises mainly because they provide evidences to mitigate chances of another crisis occurring in the future (Bakir, 2017; DE Koning, 2017, Aliber \& Zoega, 2019, Oritani, 2019). Hence, in order to enhance policies and regulations in mitigating the impact of financial crisis, this article offers a simplified evaluation of the effect of central bank measures during the 2007/2008 financial crisis.

This study reviews extant journals, book chapters, conference papers, records by reputable international organizations and news articles that have discussed this area of interest and also evaluates the most recent global economic crisis of 2007/2008 with specific focus on the major central banks, particularly the Federal Reserve (FED), European Central Bank and the Bank of England, in order to answer the central research question "How effective have conventional measures of central banks been in mitigating the impact of financial crisis?"

Besides this introduction, this article is structured as follows: Section II describes the methodology used with notable reference to the "systematic quantitative assessment technique" developed by Pickering \& Byrne (2013). Section III is devoted to results and discussion where the answer to the central research question is provided; while Sections IV and V respectively outline the conclusion and recommendations/policy implications of the study.

\section{METHODOLOGY}

\section{Information Collection}

The "systematic quantitative assessment technique" (SQAT) developed by Pickering and Byrne (2013) was used for the assessment of 'the effectiveness of conventional measures of central banks in mitigating the impact of financial crisis.' SQAT is systematic in the way papers are assessed to determine their inclusion or exclusion in the review process (Pickering \& Byrne, 2013). SQAT recommends five important steps in conducting an effective review. Each step and how it was applied in this study is described in Table 1.

Table 1: Description and Application of SQAT

\begin{tabular}{lll}
\hline S/N & Step & Application in Current Study \\
\hline $\mathbf{1}$ & Define Topic & $\begin{array}{l}\text { Effectiveness of conventional measures of central banks in } \\
\text { mitigating the impact of financial crisis }\end{array}$
\end{tabular}


2 Formulate your How effective have conventional measures of central banks

Research Question been in mitigating the impact of financial crisis?

3 Identify your Key Words
- Financial Crisis

- Central Banks

- Monetary Policy

- Conventional Measures

These are the keywords used that turned out successful in searching for the peer reviewed articles, books and conference papers.

\section{Identify and Search} Data Bases

The following 12 data bases were utilized in searching for peerreviewed empirical studies on financial crisis, with the most
5 Read and assess the publications: focus being the 2007/2008 global financial crisis: Emerald; Elsevier; Sage; Springer; Taylor and Francis; Wiley Online; Cambridge; JSTOR; Oxford; Inderscience; Ingenta; and Hein Online.

The search was conducted via google scholar through advanced search using the following combinations of the identified key phrases with all the words 'in the title' only, as follows:

- "Central Banks" + "Financial Crisis"

- "Central Banks" + "Monetary Policy"

- "Unconventional Measures" + "Financial Crisis"

Further screening was done using' return articles published in' to select data bases with peer-reviewed articles, books and conference papers such as emerald. Related articles were also reviewed during the search to search for other relevant articles. Also, quality secondary sources such as IMF reports, Basel Committee on Banking Supervision (BCBS) reports, Bank of International Settlement (BIS) reports etc. were utilized.

Only a few articles that are not peer reviewed such as newspaper publication was utilized in the introduction section to buttress the information need of the research.

Abstract of papers found in the trusted data bases were read to ensure that they are relevant to the Central Research Question.

Table 2: Time Frame: 2008-2019

\begin{tabular}{lllll}
\hline S/N & Data Base & No. of Journals & Conference & Book Chapter Newspaper \\
\hline 1 & Emerald & 1 & & \\
2 & Elsevier & 10 & 1 & 4 \\
3 & Sage & 1 & 1 & \\
4 & Springer & 7 & & \\
5 & Taylor and Francis & 2 & & \\
6 & Wiley & 5 & & \\
7 & Cambridge & 1 & & \\
8 & JSTOR & 3 & & \\
9 & Oxford & 0 & &
\end{tabular}




\begin{tabular}{llllll}
\hline 11 & Ingenta & 0 & & & \\
12 & Hein Online & 1 & & $\mathbf{4}$ & 1 \\
13 & Others & $\mathbf{2}$ & $\mathbf{2}$ & $\mathbf{4}$ & $\mathbf{1}$ \\
\hline
\end{tabular}

Table 2 describes the total number of articles, book chapters, conference papers and one newspaper article reviewed as at January 16, 2020. As can be observed in Table 2, a total of 40 items comprising 33 journal articles, five book chapters, two conference papers and one newspaper publication that met the search criteria were carefully selected and used to answer the central research question of this study.

\section{Data analysis}

In this study, empirical papers from 2008 to 2020 were analysed. The study concentrated on the analysis of empirical papers, particularly on the 2007/2008 global financial crisis. The papers were grouped and analysed based on their relevance, focus and what they intended to answer. The papers were analyzed with the central focus being how the conventional measures and unconventional measures were adjudged to deliver their desired objectives, before, during and after the crisis to determine their effectiveness. Since the 2007/2008 emanated from the U.S. and particularly affected major economies, the evidences reviewed are majorly from the Federal Reserve, European Central Bank and the Bank of England, except in few occasions to understand the spillover effect of the crisis to emerging economies.

\section{RESULTS AND DISCUSSION}

This section provides an overview of the empirical review of scholars and professionals on the background of the 2007/2008 global financial crisis, changing role of central banks, conventional measures, unconventional measures and combination of the two, so as to understand and appreciate the effectiveness of the conventional tools of central banks in mitigating the impact of financial crisis. The section also outlined the challenges faced by central banks as a result of the implementation of unconventional measures and stimulating the economy.

\section{Background of the Financial Crisis}

The 2007/2008 financial crisis, commonly termed 'Global Financial Crisis' as well as 'Great Recession,' was a severe worldwide economic crisis considered by many analysts to have been the most serious financial crisis since the Great Depression of the 1930s, to which it is regularly compared (Schoen, 2017; Khan, 2017; Aliber \& Zoega, 2019). It came after a series of crises experienced worldwide, including the East Asian crisis, the Mexican crisis, the Russian crisis, and the Latin American crisis (Wagner, 2010; Rosenhek 2013; Schoen, 2017). The crisis which originated from the US, was associated with substandard home loans that were made accessible to subprime individuals that eventually disrupted the US economy and the global economy causing unemployment, massive declines in gross domestic product, and the prolonged mortgage foreclosure crisis (Westercamp, 2009; Schoen, 2017; Aliber \& Zoega, 2019). It affected the developed markets of Europe and North America as well as numerous emerging and developing market economies making it a global issue (Grosse, 2017; Yuksel, 2017; Aliber \& Zoega, 2019). The crisis rapidly spread all over the global financial system, indicating how intertwined and interconnected financial institutions are worldwide (Kotz, 2009; Wagner, 2010; Aliber \& Zoega, 2019). Rationally, the crisis should have ravaged only a small portion of activelytraded mortgage-backed securities and collateralized debt obligations but empirically, when the value of the mortgage-backed bonds began to plummet, investors panicked and started uploading 
their holdings, which led the crisis to extend across a wide range of hedge funds and financial institutions around the globe (Westercamp, 2010; Wagner, 2010; Hudson and Maioli, 2010).

The bankruptcy of Lehman Brothers in 2008 is considered the single-most important occurrence that sent the global markets into chaos and considered by most as the climax point in the Global Financial Crisis (Arestis, 2017; Cukierman, 2019; Oritani, 2019). Unlike Bear-Stearns that was rescued, the Fed's unwillingness to save Lehman was due to the absence of U.S. Congress approval for further bailout fund and the fact that other significant financial institutions including American International Group (AIG), Washington Mutual and Merrill Lynch, were also on the edge of financial collapse (Gertler \& Gilchrist, 2018; Cukierman, 2019; Oritani, 2019). Lehman's bankruptcy, which could have been averted, magnified the credit apprehension that had started turning to a major financial panic (Mishkin, 2009; Arestis, 2017; Oritani, 2019). The panic due to the collapse of Lehman was greater than expected, and the United States Congress had to eventually approve a bailout by the fiscal authority under the Troubled Assets Relief Program (TARP) legislation included in the Emergency Economic Stabilization Act of October 2008 (Schoen, 2017; Gertler \& Gilchrist, 2018; Oritani, 2019). A lesson derived from this experience is that the ability to speedily commit fiscal funds in an emergency situation can minimise the possibility of imminent financial panics or crisis (Gertler \& Gilchrist, 2018; Cukierman; 2019; Oritani, 2019).

Even though the Crisis began in the U.S.A., its speedy spread has been attributed to many other factors linked to globalization and interconnectedness of the financial system (Wagner, 2010; Ojo, 2011; Rosenhek, 2013). Other factors included the criticism of loose monetary policy implementation by major central banks like the Federal Reserve and European Central Bank; political meddling; the business models of investment bankers, particularly securitization; and failures of financial regulatory institutions arising from their inability to keep pace with major changes in financial markets, firms, and products (Ojo, 2011; Rosenhek, 2013; Bakir, 2017; Schoen, 2017.) Furthermore, investors and financial institutions extremely relying on the evaluations of the credit rating agencies, who had poor understanding of the complex financial instruments introduced, was another factor (Ojo, 2011; Rosenhek, 2013; Bakir, 2017, Schoen, 2017). When the crisis reached a critical state, the Federal Reserve Bank had to shift most of its policy instruments away from inflation targeting, which was the accepted norm for the central bank policy to financial stability (Gertler, 2013; Gambacorta et al., 2014; Rajan, 2017).

\section{The Changing Role of Central Banks}

The commonly recognized objectives or mandates of central banks around the world include: Financial stability and price stability (Klomp \& Hann, 2009; Wagner, 2010; Goodhart, 2011). Financial stability refers to the smooth functioning of the various components of the financial system such as financial institutions, financial markets and payment/settlement/clearing systems (Klomp, 2009; Ojo, 2011; Bakir 2011). "It is confirmed that financial stability was more likely when there is seamless interactions between structural and institutional agents in a country (Klomp, 2009; Ojo, 2011; Bakir, 2011). Every country has a central bank that facilitates monetary policy objectives and ensures the smooth operations of its financial systems (Goodhart, 2011; Arestis, 2017; Yuksel, 2017). Central banks are the major determinants of monetary policy worldwide to ensure price stability, but also serve other important functions including being the lender of last resort (Goodhart, 2011; Rosenhek, 2013; Arestis, 2017). The 'lender of last resort' is a tool available to central banks to assist financial institutions in crisis (Goodhart, 2011; Cukierman, 2019; Oritani, 2019). The existence of a lender of last resort is, however, often associated with the moral hazard of financial institutions believing that in crisis situations the central bank will always intervene to prevent their failure, which could therefore encourage excessive risk takings (Goodhart, 2011; Cukierman, 2019; Oritani, 2019)". 
Central banks are the institutions expected to act first whenever there is financial crisis and therefore are expected to have realistic financial stability objectives (Klomp \& Hann, 2009; Wagner, 2010; Goodhart, 2011). "The last global financial crisis confirmed the importance of complementarity and synergies that exist between financial stability and monetary policy, which made them often difficult to separate in practice (Wagner, 2010; Khan, 2017; Bakir; 2017)". Undeniably, the crisis that emerged worldwide, required a systemic intervention by the central banks, particularly of advanced countries, thereby compelling them to review their monetary policy approaches (Gertler, 2013; Gambacorta et al., 2014; Chen et al., 2016). The crisis further proved the state of critical urgency for central banks to establish macro prudential frameworks so as to proactively monitor individual institutions and interconnected markets for early warning signs as part of financial stability objectives (Goodhart, 2011; Khan, 2017; Bakir, 2017). It became paramount that close collaboration and active information sharing between regulatory authorities and central banks must take place for the operationalization of the macro prudential framework in bridging the gap between macroeconomic policies and regulation of individual financial institutions (Goodhart, 2011; Michael et al., 2012; Khan, 2017). For example, "Australia and Canada had complementarities arising from monetary, fiscal, market, macroeconomic, policy and political structures as well as those arising from prudential and competition regulations that reinforces the prudent behavior of various private and public sector players, thereby contributing to financial stability (Khan, 2017, Arestis, 2017; Bakir, 2017)."

The global financial crisis has made governments and central banks, particularly, in major advanced economies to take a wide range of measures to address the tensions in the global financial markets (Westercamp, 2009; Gambacorta et al., 2014; Tillman, 2016).

\section{Conventional Measures}

Decades before the Global Financial Crisis, central banks followed the same rationality of the Taylor rule in obtaining a target inflation rate in line with their level of likely activities (Gerlach \& Schnabel, 2000; Michael et al., 2012; Mishkin, 2017). Conventional Monetary Policy commonly refers to the use of inflation targeting strategies to achieve stable and low inflation and maintain price stability, particularly in the U.S. and many other central banks in the developed and emerging economies (Mishkin, 2010; Cukierman, 2013; Mishkin, 2017). These were accomplished through a series of monetary policy instruments including Open-market operations; mandatory reserves; facilities used to provide and withdraw overnight liquidity; determine upper and lower limit for the overnight market interest rates; and manage liquidity situation in the money market and signaling the stance of monetary policy (Gerlach \& Schnabel; 2000; Cukierman, 2013; Mishkin, 2017). Particularly in the U.S., the Federal Fund Rate, which is the main and most frequent used instrument that affects all market participants was pushed several times down to the zero-lower bound, in order to contain the escalation of the 2007/2008 financial crisis (Westercamp, 2009; Mishkin, 2017; Cukierman, 2019). Similar stance was taken by the European Central Bank and the Bank of England (Fratzscher, et al., 2016; Arestis, 2017; Horvath \& Voslarova, 2017). The supremacy of the conventional monetary policy was put to test as never before since the main tool of monetary policy had accordingly been pushed to the limit of its efficiency (Hamilton \& Wu, 2012; Gambacorta et al. 2014; Cukierman, 2019). This constrained the interest rate channel of monetary transmission mechanism since rate was effectively zero and could not go any lower to stimulate the real economy (Hamilton and Wu, 2012; Gambacorta et al. 2014; Cukierman, 2019).

The crisis further revealed that the relationship between official and market rates also broke down since the financial system was severely disrupted, while insolvency increased along with a belief that banks were holding onto funds rather than lending for their viability, openly causing credit crunch thereby affecting the credit channel of monetary transmission (Bowdler \& Radia, 2012; Grosse, 2017; Cukierman, 2019). This constituted additional constraint to the 
monetary transmission mechanism via the credit channel (Bowdler \& Radia, 2012; Grosse, 2017; Cukierman, 2019). Also, regulatory stringencies increased costs for firms and institutions, lowering returns on investment and innovation, negating the positive impacts of a loose monetary stance (Bowdler \& Radia, 2012; Khan, 2017; Cukierman, 2019). The global financial crisis revealed that while conventional monetary measures achieved low and stable inflation, they could not stop asset bubbles (Mishkin, 2009; Hamilton and Wu, 2012; Cukierman; 2019).

The crisis generally proved the use of conventional measures alone to be unproductive in achieving the desired result because the monetary transmissions were not working and the usual rate did not impact market as expected in line with the Taylor's Rule (Michael et al., 2012; Bowdler \& Radia, 2012; Grosse, 2017; Cukierman, 2019). However, it was widely believed and proved that conventional measures and macro-prudential tools will jointly achieve financial and price stability when recovery occurs (Michael et al., 2012; Rosenhek, 2013; Mishkin, 2017).

\section{Unconventional Measures}

While central banks strongly believed that conventional monetary policy combined with macro prudential tools will jointly achieve price and financial stability when recovery occurs, the challenge was how to stimulate the economy so as to reach that point (Michael et al., 2012; Rosenhek, 2013; Mishkin, 2017). The major central banks, notably the Federal Reserve, European Central Bank and the Bank of England, were challenged almost concurrently to provide unprecedented support to financial institutions to enable recovery (Westercamp, 2010; Hudson \& Maioli, 2010; Arestis, 2017). At that point, they had to recognize the limitations of conventional monetary policy during the period of acute crisis (Westercamp, 2010; Hudson \& Maioli, 2010; Arestis, 2017). These major central banks as well as other central banks around the world actively responded to the crisis with unconventional monetary policy measures, using their balance sheets to re-establish the effectiveness of the credit market, liquidity positions and restore investor confidence (Westercamp, 2010; Hudson \& Maioli, 2010; Cukierman, 2019). These measures were justified to maintain price stability and acted their roles as lenders of last resort in a new dimension by providing liquidity for the entire financial system (Klomp \& Hann, 2009; Goodhart, 2011; Rosenhek, 2013).

The most prominent unconventional monetary measure utilized was Quantitative Easing, which was first adopted by Japan when it dealt with the consequences of real estate bubble burst (Bowdler \& Radia, 2012; Michael et al., 2012; Arestis, 2017). This is otherwise known as balance sheet policies as it essentially causes immense expansion of central bank's balance sheet and liabilities structure (Gertler, 2013; Tillmann, 2016; Arestis, 2017). Quantitative Easing started after the collapse of Lehman Brothers, aimed at meeting the enormous rise in demand for liquidity due to the panic but the major objective changed to stimulation of the entire economic activity in a Zero Lower Bound environment, resulting from gradual descent of the federal funds rate for two years (Gambacorta et al. 2014; Gertler \& Gilchrist, 2018; Cukierman, 2019). The Fed introduced Quantitative Easing in several episodes (i.e. QE1, QE2, QE3) having different rationale across each measure and episode (Bowdler and Radia, 2012; Gertler, 2013; Tillmann, 2016). However, all the measures were directed towards expediting recovery from the crisis through the improvement of financial condition of financial institutions (Bowdler \& Radia, 2012; Gertler, 2013; Tillmann, 2016).

Specifically, the Fed used Quantitative Easing and Forward Guidance classified under interest policy, credit policy and quantitative easing in the wake of the global financial crisis (Bowdler and Radia, 2012; Gertler, 2013; Mishkin, 2017). For instance, the Fed implemented credit easing policies by purchasing mortgage-backed securities, which expanded its balance sheet by holding more assets and provided liquidity to the dried-up market as well as credit lines to an important segment of the economy (Michael et al., 2012; Mishkin, 2009; Schoen, 2017). 
The Fed also overwhelmingly bought US treasuries, agency debt and agency-backed mortgagebacked securities (Rosenhek, 2013; Arestis, 2017; Schoen; 2017). In the same vein, the Bank of England bought a significant quantity of UK government bonds from the non-bank private sector through its Quantitative Easing operations (Goodhart, 2011; Hamilton \& Wu, 2012; Arestis, 2017). Great similarities were observed between the assets bought by the Fed and the Bank of England because the bulk of the mortgage-backed securities were effectively government agencies since they are guaranteed by the U.S. agencies (Goodhart, 2011; Hamilton \& Wu, 2012; Arestis, 2017). The European Central Bank also expanded its balance sheet through the provision of collateralized loans, termed repo operations (Falagiarda \& Reitz, 2015; Fratzscher et al., 2016; Horvath \& Voslarova, 2017).

In terms of spillovers, a typical quantitative easing shock was shown to have almost the same responses of emerging economies' bond prices as typical cut in the federal fund rate, that is, no difference between conventional and non-conventional (Fratzscher, et al., 2016; Chen et al., 2016; Tillmann, 2016). While the impact of the U.S. first step of quantitative easing (QE1) was found to be limited on emerging markets, QE2 and QE3 impacts were substantial by reducing the risk of deflation and hastening the exit from the crisis (Fratzscher, et al., 2016; Chen et al., 2016; Tillmann, 2016). The ECB policies also demonstrated positive spillovers by increasing equity prices and reducing credit risk and risk aversion in Central Europe and other parts of the world (Fratzscher, et al., 2016; Tillmann, 2016; Horvath \& Voslarova, 2017).

While the ECB used a conservative approach by placing greater emphasis on supporting banks in the euro area due to their reliance on bank intermediation, Fed's intervention was a comprehensive approach that included mainly non-bank credit markets in agreement with its market based financial system (Michael et al., 2012; Rosenhek, 2013; Falagiarda \& Reitz, 2015; Arestis, 2017).

\section{Effectiveness of Conventional Measures}

The great and far reaching global financial crisis also known as global recession had naturally given rise to a wide variety of responses and reflections (Westercamp, 2009; Hudson \& Maioli, 2010; Mishkin, 2017). Although various literatures had blamed different quotas on issues including delayed response, but the general consensus was that the response had been swift (Wagner, 2010; Rosenhek, 2013; Arestis, 2017). If the Fed had not been decisive and cut rates aggressively, the consequence would have been both significant increase in macro-economic risk with higher credit spread and higher interest rates on Treasury securities (Mishkin, 2009; Rosenhek, 2013; Schoen, 2017). Interest rates relevant to household consumers and business spending decisions would have been much higher than what was seen during the crisis and would have seriously affected aggregate spending, which in turn would have made the recession more severe (Mishkin, 2009; Rosenhek, 2013; Schoen, 2017). This logic indicated that not only has conventional monetary policy been effective during the global financial crisis but was even more potent than during normal times since it helped to lower credit spreads (Mishkin, 2009; Rosenhek, 2013; Schoen, 2017). However, the financial crisis led to such wide credit spreads and tightening of credit ethics, that made aggressive monetary policy insufficient to address the crisis (Westercamp, 2009; Gerlach \& Schnabel, 2000; Cukierman, 2013). This led to the utilization of complimentary measures otherwise known as non-conventional measures to achieve the desired objective of mitigating the crisis (Hamilton \& Wu, 2012; Gambacorta et al. 2014; Cukierman, 2019).

However, the multifaceted nature of the financial crisis highlighted the limitation of monetary policy, no matter how aggressive, in addressing the crisis. The financial crisis affected several angles such as financial, monetary, growth socio/political and psychological. This underscores the need for financial stability structure to include monetary authorities i.e. central 
banks in most jurisdictions; all other financial regulators (insurance, pension, security exchange, stock exchange etc.); and fiscal authorities (government establishments).

\section{CONCLUSION}

The 2007/2008 Global Financial Crisis was a severe worldwide economic crisis considered by many analysts to have been the most serious financial crisis since the Great Depression of the 1930s, to which it is regularly compared. There has been growing concern among scholars about the role of central banks in mitigating financial crisis. A growing body of empirical literature analysed what went wrong, lessons learnt and how to prevent next one and the need for an empirical analysis of the measures used in mitigating financial and economic crisis appeared to be justified. Moreover, there is no doubt that the global financial crisis and its aftermath of the worst global recession since the 1930s poses many challenges for monetary policy and central banks. During the crisis, while conventional measures of monetary policy achieved a low and stable inflation, it failed to prevent asset market bubbles from occurring and stir the economy back to recovery. Indeed, it was discovered that most central banks deployed unconventional measures in mitigating the crisis.

This study has demonstrated that central banks, though intensely shaken by the global financial crisis, have not practically abandoned the core elements of their pre-crisis monetary policy. Through a complex form of strengthening and reassessment, they have instead complimented, extended and somewhat improved their measures to mitigate the impact of the financial crisis. An important lesson of the crisis is that there is opportunity to reinforce central banks with macro prudential supervision and regulation. This should be seen as complementary to the existing monetary policy measures in order to deliver the twin objectives of price stability and financial stability. In a nutshell, conventional monetary policy can make an important contribution to financial stability. However, the set of monetary policy instruments applied may be unsuitable in certain circumstances. Accordingly, instruments that have a direct effect are needed, as compliments to counter the emergence of financial instabilities.

\section{POLICY IMPLICATIONS/RECOMMENDATIONS}

The causes, consequences and implications of financial crisis had been extensively debated and many authors made various recommendations for future policies. The use of conventional and/or non-conventional policies during the 2007 global financial crisis and other crises that preceded it were also widely debated. It was particularly acknowledged that the quantitative easing, which is a popular type of unconventional measure originated from Japan when it dealt with the real estate bubble burst and its consequences. Based on the analysis of scholars and professionals, it is evident that conventional measures of central banks are potent in mitigating the impact of financial crisis but not necessarily sufficient under certain circumstances, particularly in preventing asset market bubbles from occurring. Therefore, unconventional measures are complimentary to conventional monetary policy measures. These are distinct from the conventional monetary measures of targeting short-term interest rate. It is important to note that implementing and exiting from these distinct measures poses a number of practical challenges such as calibrating and communication of the policy; relationship with fiscal policy; exposure of central banks to financial risk; and most importantly, sustaining the utilization of such policies. While central banks may want to retain some features of these new innovations associated with unconventional monetary policy in their operating procedures, they are likely to be used only in exceptional circumstances.

An important policy lesson from the global financial crisis is the collapse of Lehman Brothers, which is a Systematically Important Financial Institution (SIFI). In this regard, the Basel 
Committee of Banking Supervision has recommended a robust guideline for the conduct of SIFIs and recommended a recovery and resolution planning mechanism for such institutions.

There is also the need for several reforms in the legal and institutional frameworks of central banks, particularly those of the emerging economies. The multifaceted financial stability structure along with the macro prudential framework and other regulatory and supervisory enhancements of the central banks will go a long way in mitigation of financial crisis.

Along with the increase in globalization and financialization, with the increased role of central banks in macro prudential supervision and regulation; enhanced cross border supervision, Basel III implementation, macro prudential framework and many other regulatory and supervisory tightening around the world, it is worthy to note that central banks and international financial organizations have further strengthen their conventional policies of regulations and supervision to ring-fence and wither the next financial crisis.

\section{REFERENCES}

Aliber, R. Z., \& Zoega, G. (2019). A Retrospective on the 2008 Global Financial Crisis. In The 2008 Global Financial Crisis in Retrospect (pp. 1-15). Cham, Switzerland, Palgrave Macmillan.

Arestis, P. (2017). Monetary policy since the global financial crisis. In Economic Policies since the Global Financial Crisis (pp. 1-39). Cham, Switzerland, Palgrave Macmillan.

Bakir, C. (2017). How can interactions among interdependent structures, institutions, and agents inform financial stability? What we have still to learn from global financial crisis. Policy Sciences, 50(2), 217-239.

Bordo, M. D., \& Haubrich, J. G. (2017). Deep recessions, fast recoveries, and financial crises: Evidence from the American record. Economic Inquiry, 55(1), 527-541.

Bowdler, C., \& Radia, A. (2012). Unconventional monetary policy: the assessment. Oxford Review of Economic Policy 28(4), 603-621.

Brown R., (2019) Deutsche Bank CEO warns central banks have no tools left to 'cushion' a 'real economic crisis. available at: https://www.cnbc.com/2019/09/25/deutsche-bank-ceocentral-banks-have-no-tools-left-to-cushion-crisis.html?\&qsearchterm=deusche bank ceo warns (accessed November 4, 2019)

Correia, L., \& Martins, P. (2017). The Global Financial Crisis: From US Subprime Mortgages to European Sovereign Debt by George K. Zestos. Panoeconomicus, 64(5), 657-662.

Chen, Q., Filardo, A., He, D., \& Zhu, F. (2016). Financial crisis, US unconventional monetary policy and international spillovers. Journal of International Money and Finance, 67, 62-81.

Cukierman, A. (2019). A retrospective on the subprime crisis and its aftermath ten years after Lehman's collapse. Economic Systems, 43(3-4), 100713.

Cukierman, A. (2013). Monetary policy and institutions before, during, and after the global financial crisis. Journal of Financial Stability, 9(3), 373-384.

Da Silva, C. G., \& Vieira, F. V. (2017). Monetary and fiscal policy in advanced and developing countries: An analysis before and after the financial crisis. The Quarterly Review of Economics and Finance, 63, 13-20. 
Falagiarda, M., \& Reitz, S. (2015). Announcements of ECB unconventional programs: Implications for the sovereign spreads of stressed euro area countries. Journal of International Money and Finance, 53, 276-295.

Fratzscher, M., Duca, M. L., \& Straub, R. (2016). ECB unconventional monetary policy: Market impact and international spillovers. IMF Economic Review, 64(1), 36-74.

Gagnon, J. E., Bayoumi, T., Londono, J. M., Saborowski, C., \& Sapriza, H. (2017). Direct and spillover effects of unconventional monetary and exchange rate policies. Open Economies Review, 28(2), 191-232.

Gambacorta, L., Hofmann, B., \& Peersman, G. (2014). The effectiveness of unconventional monetary policy at the zero lower bound: A cross-country analysis. Journal of Money, Credit and Banking, 46(4), 615-642.

Gerlach, S., \& Schnabel, G. (2000). The Taylor rule and interest rates in the EMU area. Economics Letters, 67(2), 165-171.

Gertler, M. (2013). Monetary policy after August 2007. The Journal of Economic Education, 44(4), 329-338.

Gertler, M., \& Gilchrist, S. (2018). What happened: Financial factors in the great recession. Journal of Economic Perspectives, 32(3), 3-30.

Goodhart, C. A. E. (2011). The changing role of central banks. Financial History Review, 18(2), 135-154.

Grosse, R. (2017). The global financial crisis-Market misconduct and regulation from a behavioral view. Research in International Business and Finance, 41, 387-398.

Hamilton, J. D., \& Wu, J. C. (2012). The effectiveness of alternative monetary policy tools in a zero lower bound environment. Journal of Money, Credit and Banking, 44, 3-46.

Horvath, R., \& Voslarova, K. (2017). International spillovers of ECB's unconventional monetary policy: the effect on Central Europe. Applied Economics, 49(24), 2352-2364.

Hudson, R., \& Maioli, S. (2010). A response to "Reflections on a global financial crisis". Critical perspectives on international business, 6(1), 53-71.

Joyce, M., Miles, D., Scott, A., \& Vayanos, D. (2012). Quantitative easing and unconventional monetary policy-an introduction. The Economic Journal, 122(564), 271-288.

Khan, A. (2017). Central Bank legal frameworks in the aftermath of the global financial crisis, IMF Working Paper, International Monetary Fund. http://www.imf.org/external/pubs/pubs/ord_info.htm

Klomp, J., \& De Haan, J. (2009). Central bank independence and financial instability. Journal of Financial Stability, 5(4), 321-338.

Kotz, D. M. (2009). The financial and economic crisis of 2008: A systemic crisis of neoliberal capitalism. Review of radical political economics, 41(3), 305-317.

Mamun, A. (2017). An Investigation of the Factors Causing Financial Crisis: Lessons from Recent Overwhelming Episodes. Journal of Academic Research in Economics (Jare), 9(1), 7-18.

Mishkin, F. S. (2009). Is Monetary Policy Effective during Financial Crises? The American Economic Review, 99(2), 573-577.

Mishkin, F. S. (2010). Monetary policy flexibility, risk management, and financial disruptions. Journal of Asian Economics, 21(3), 242-246. 
Mishkin, F. S. (2017). Rethinking monetary policy after the crisis. Journal of International Money and Finance, 73, 252-274.

Nastase, M., Cretu, A.S. \& Stanef, R. (2010). Effects of Global Financial Crisis. Metarlurgia, 10(4), 691-699.

Ojo, M. (2011). The changing role of central banks and the role of competition in financial regulation during (and in the aftermath of) the financial crisis. European Law Journal, 17(4), 513-533.

Oritani, Y. (2019). Role of Central Banks in Financial Crisis Management. In The Japanese Central Banking System Compared with Its European and American Counterparts (pp. 229-265) Singapore.

Rajan, R. (2017). Unconventional monetary policy and the role of central banks. Business Economics, 52(4), 189-193

Rosenhek, Z. (2013). Diagnosing and explaining the global financial crisis: Central banks, epistemic authority, and sense making. International Journal of Politics, Culture, and Society, 26(3), 255-272.

Schoen, E. J. (2017). The 2007-2009 financial crisis: An erosion of ethics: A case study. Journal of Business Ethics, 146(4), 805-830.

Tillmann, P. (2016). Unconventional monetary policy and the spillovers to emerging markets. Journal of International Money and Finance, 66, 136-156.

Wagner, H. (2010). The causes of the recent financial crisis and the role of central banks in avoiding the next one. International Economics and Economic Policy, 7(1), 63-82.

Westercamp, K. M. (2009). A Crack in the Facade and the Whole Building Came Tumbling Down: A Critical Examination of the Central Banks' Response to the Subprime Mortgage Loan Crisis and Global Financial Market Turmoil. Transnat'l L. \& Contemp. Probs., 18, 197244.

Yüksel, S. (2017). Strategies Out of Global Recession in Emerging Markets: An Application for 2008 Global Crisis. In Global Business Strategies in Crisis (pp. 57-75). Cham, Switzerland

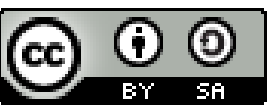

(C) 2021 by the authors. Submitted for possible open access publication under the terms and conditions of the Creative Commons Attribution (CC BY SA) Creative Commons Atribusi-BerbagiSerupa 4.0 Internasional. 